\title{
Intermédialités
}

Histoire et théorie des arts, des lettres et des techniques

Intermediality

History and Theory of the Arts, Literature and Technologies

\section{Synchronizations at Work: Anette Rose's Encyclopaedia of Manual Operations}

\section{Ines Lindner}

Numéro 19, printemps 2012

URI : https://id.erudit.org/iderudit/1012661ar

DOI : https://doi.org/10.7202/1012661ar

Aller au sommaire du numéro

Éditeur(s)

Revue intermédialités (Presses de l’Université de Montréal)

ISSN

1705-8546 (imprimé)

1920-3136 (numérique)

Découvrir la revue

Citer cet article

Lindner, I. (2012). Synchronizations at Work: Anette Rose's Encyclopaedia of Manual Operations. Intermédialités / Intermediality, (19), 157-159.

https://doi.org/10.7202/1012661ar d'utilisation que vous pouvez consulter en ligne. 


\title{
Synchronizations at Work: Anette Rose's Encyclopædia of Manual Operations
}

\author{
lNES LiNDNER
}

E

very synchronization implies a process of reconcilement based on the coordination of a variety of procedures. Synchronizations are geared toward repeatability; they are also reproducible. This applies to technical processes, and also to the coordination of bodily movements. While a machine only needs to be programmed once, the synchronization of movements involved in dancing or sawing, for example, must be learned over time. With practice, the movement sequence gradually becomes engrained in the person's flesh and blood. After a certain period, the required coordination processes begin to operate unconsciously, but not automatically. An experienced worker will notice deviations from the normal production process and carry out a resynchronization, whereas a machine stops and signals an error message.

Anthropology and occupational physiology began to take an interest in these processes at around the same time; anthropologists carried out research on cultural differences in basic bodily techniques, ${ }^{1}$ while occupational physiologists investigated the possibilities for optimizing manual work movements in production processes. ${ }^{2}$ In these two areas of research, the study of media recordings provides both the condition and the basis for a systematic assessment of the motion sequences under investigation. Visibility first has to be generated; this creates new images, which can then be reproduced, compared and analyzed.

Anette Rose has worked with both areas in her research for the long-term project "Enzyklopädie der Handhabungen" (Encyclopaedia of Manual Operations).

1. Marcel Mauss summarized his observations made after WWI in the lecture «Les techniques du corps» [1934], in Sociologie et anthropologie, Paris, PUF, coll. «Bibliothèque de sociologie contemporaine », 1968.

2. Frank Bunker Gilbreth and Lillian Moller Gilbreth, Applied Motion Study. A Collection of Papers on the Efficient Method to Industrial Preparedness, New York, Macmillan, 1919 . 
She quotes from visual material from anthropology and occupational physiology in photo montages, which are then used in her works. ${ }^{3}$ The focal point of the project is the issue of "haptic" intelligence. The physiological structure of the hand and its various cultural significances are extremely complex. The artist observes the visual expression of the coordination of hand and eye, of facial expressions and gestures.

She visits a number of companies and research laboratories in order to film workers' gestures and the various stages of mechanization of these gestures. She uses two cameras to film the face and the hands of workers separately. In her video installations, this recorded material is recombined and resynchronized on two monitors or projection screens. There is no off-camera explanation, no narration, only precise observation, with the rhythmic noise of manual operations and machines in the background. The artist focuses our attention on the interplay of these faces and hands by displaying the images synchronously.

The work gestures are filmed in companies where there are varying degrees of automation. In some cases, gripper robots have already replaced the hand. However, the versatility and the flexibility of coordination between the hand and the eye are still difficult to replace. Anette Rose observes this procedure with curiosity, but without nostalgia. For example, manual work in the production of porcelain is presented alongside fully automated production processes. In this way, an archive of contemporary industrial work is gradually developed.

A further dimension is given to this survey by the artist's research work, where she interviews specialists who explain and reflect upon the production processes. She observes their facial expressions and gestures during these conversations, which are also filmed using two separate cameras. An important characteristic of Anette Rose's work is that she does not differentiate between factory workers and specialists in her film footage, so as not to reproduce different social perceptions that are based on the separation of manual labour and intellectual work.

The establishment of uniform parameters accords equal status to the different types of work and expressive gestures observed. The looped material of the gestures can be freely combined in various ways for each installation and can be adapted to different exhibition spaces.

Anette Rose's video work is conceptual in approach, minimalistic in form, and documentary in terms of content. Her set photos show the working environment and reflect her working method at each location.

3. Anette Rose, Enzyklopädie der Handhabungen 2006-2010, Bielefeld, Kerber Verlag, 2011, Photo montage p. 77-108. 
Much of the fascinating quality of the Enzyklopädie der Handhabungen lies in the fact that the images of faces and hands, and their half-conscious interplay, are radically reduced to their basic visibility; this stands in tension with the broad epistemological interest which drives Rose's work. Her core concern here is nothing less than the visual capture of fundamental social facts. Beyond all discourse, concrete awareness is generated here for processes that generally receive little attention, but which nonetheless shape our everyday lives.

Both the ambition of this long-term project and its visual precision position the Enzyklopädie der Handhabungen within a tradition that ranges from August Sander's class portraits ${ }^{4}$ through to Bernd and Hilla Becher's photographs of industrial buildings and structures. ${ }^{5}$ There have also been long-term projects in documentary filmmaking that carve out social facts, but, to date, still photography is the only medium to have provided visual typologies that are graspable with a comparing gaze.

The loops repeat the various working and expressive gestures, thus allowing the observer to compare them. Where the Bechers combined their anonymous architectures to create photo arrays on two-dimensional surfaces, Anette Rose combines her loops in space. With these precisely coordinated loops, a polyphonic structure is created that allows similarities and differences to be recognized.

Synchronizations at Work can refer to both the observations that Anette Rose develops in each module and the combination of these observations in the video installations. Her main concern in focusing on synchronization is to investigate anonymous work processes that shape the foundation of our living conditions.

4. August Sander, Face of our Time [1929], with a foreword by Alfred Döblin, München, Schirmer/Mosel, 2008. Walter Benjamin offers a detailed discussion of this piece, which is comprised of 45 folders, each containing 12 photos, in the collection review "Little History of Photography," [1931] in Walter Benjamin, Selected Writings, Volume 2 (1927-1934), Michael W. Jennings, Howard Eiland and Gary Smith (eds.), Cambridge (Mass.), Harvard University Press, 1999, p. 507-530.

5. Bernd and Hilla Becher, Typologien industrieller Bauten, München, Schirmer/ Mosel, 1990. In 1990, the Bechers were awarded the Golden Lion at the Venice Biennale. Their students have included Candida Höfer, Andreas Gursky and Thomas Ruff. 